\title{
Proses Pembuktian Penguasaan Narkotika yang Disimpan di Dalam Helm
}

\author{
Antonius Sony Wijanarko
}

sonywijanarko2112@gmail.com

\begin{abstract}
Abstract - This article aims to examine the proofing of crystal-methamphetamine found inside drug dealer-alleged helmet. Research in this paper used a normative juridical research method, which was examining primary legal materials consist of legislations and regulations. Beside the primary legal materials, this study was also conducted using secondary legal materials consist of doctrines, principles, and scientific writings that can be found in various literature that are closely related to primary law to answer the problem in this research.
\end{abstract}

Keywords: Legal proofing, possesion, narcotics.

\section{Pendahuluan}

Narkotika pada dasarnya digunakan sebagai obat atau bahan yang memiliki manfaat cukup penting dalam proses pengobatan atau pelayanan kesehatan serta berguna untuk pengembangan ilmu pengetahuan. Narkotika adalah sesuatu yang memiliki banyak manfaat sedangkan yang dilarang adalah penyalahgunaannya. Pada kenyataannya Narkotika memiliki efek samping seperti menyebabkan ketergantungan atau kecanduan yang dapat merugikan apabila disalahgunakan dengan mengonsumsi Narkotika tersebut tanpa adanya pengendalian dan pengawasan yang ketat dan seksama oleh pihak yang berwenang.

Penyalahgunaan Narkotika saat ini sudah sampai pada taraf yang memprihatinkan bukan hanya kuantitas penyalahgunaan yang semakin banyak dan meluas akan tetapi penggunaanya juga telah menjalar hampir ke lapisan masyarakat mulai dari pelajar hingga pejabat Negara pun terlibat dalam tindak pidana Narkotika ini. Peredaran Narkotika di Indonesia mempunyai kecenderungan meningkat dan yang sangat disayangkan pengguna Narkotika saat ini sudah mulai dilakukan aparat Pemerintah dan penegak Hukum.

Penyalahgunaan Narkotika dan obat-obatan yang termasuk golongan terlarang di Indonesia beberapa tahun terakhir ini menempati masalah yang cukup serius bahkan dinyatakan masalah dalam keadaan yang mengkhawatirkan sehingga menjadi masalah tingkat nasional di Indonesia. Korban penyalahgunaan Narkotika tanpa disadari telah meluas sedemikian rupa sehingga melewati batas-batas strata sosial, umur dan jenis kelamin. Perluasannya tidak hanya pada daerah perkotaan tetapi pada daerah pedesaan juga menjadi sasaran dari peredaran Narkotika dan juga hingga melampaui batasan Negara yang memiliki akibat seperti merugikan warga, masyarakat, bahkan Negara terutama yang menjadi sasarannya adalah generasi muda yang dapat menimbulkan kecemasan dan keresahan serta bahaya yang cukup besar bagi

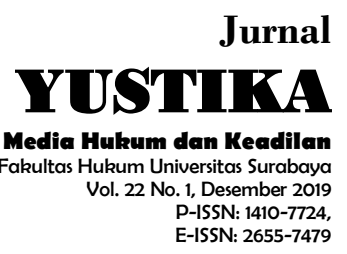


Jurnal Yustika

Vol. 22 No. 1, Des 2019

Halaman | 65

Proses Pembuktian

Penguasaan

Narkotika yang

Disimpan di Dalam

Helm

Antonius Sony Wijanarko kehidupan masyarakat dan nilai-nilai budaya bangsa yang pada akhirnya juga dapat mengurangi sistem keamanan negara.

Undang-undang Nomor 35 Tahun 2009 merupakan salah satu peraturan tertulis yang dibuat oleh lembaga berwenang dan berlaku umum sehingga aturan tersebut harus ditegakkan sekalipun dengan cara represif. Dalam sistem hukum di Indonesia, suatu Hukum yang baik akan dapat berjalan apabila ada suatu substansi yang dapat bermanfaat sebagai sarana penegak keadilan dan didukung aparat penegak Hukum yang konsisten mengikuti substansi tersebut maupun konsisten menjunjung hak asasi manusia.

"Proses peradilan Pidana bertujuan mencari dan mendapatkan kebenaran materiil yaitu kebenaran yang selengkap-lengkapnya dari suatu perkara pidana dengan menerapkan ketentuan hukum acara secara jujur dan tepat atau due process of law yaitu selain dari penerapan Hukum atau perundang-undangan secara formal, harus pula memberikan jaminan perlindungan dan kepastian Hukum terhadap warga Negara untuk memperoleh peradilan yang adil dan tidak memihak berdasarkan hak asasi manusia". (Dahlan, 2017, hal. 5).

Tindak Pidana Narkotika saat ini telah menjadi permasalahan yang sangat kompleks dan perlu ditanggapi serius oleh masyarakat dunia khususnya Indonesia. Dalam proses pembuktian kasus Narkotika, seringkali alat bukti yang digunakan adalah dua orang saksi, barang bukti sejumlah narkoba, hasil tes urine atau tes darah milik terdakwa. Hal tersebut memang sudah cukup kuat dalam pembuktian sebagaimana dimaksud dalam KUHAP, namun sistem pembuktian negatif yang dianut oleh KUHAP mengharuskan adanya keyakinan Hakim agar terdakwa dapat dijatuhi sanksi pidana. Dalam kasus penjatuhan putusan bebas terhadap pelaku tindak Pidana Narkotika ini tidak hanya terjadi di daerah Pekalongan dan di daerah Banjarmasin saja tetapi juga di Surabaya yaitu di mana terdakwa tersebut telah tertangkap tangan membawa Narkotika jenis sabu-sabu tetapi oleh hakim terdakwa tersebut diputus bebas. Berdasarkan uraian tersebut dapat dijadikan rumusan masalah yaitu Proses pembuktian penguasaan Narkotika pada kasus ditemukannya Narkotika di dalam helm berdasarkan hukum pidana formil yang berlaku.

\section{Metode Penelitian}

Metode penelitian yang digunakan dalam penulisan ini adalah :

a. Tipe Penelitian

Tipe penelitian dalam metode ini adalah penelitian hukum yuridis normatif, yang merupakan penelitian yang didasarkan pada studi kepustakaan yang meliputi bahan hukum primer dan bahan hukum sekunder yang terdiri dari peraturan perundang-undangan yaitu Undang-Undang Nomor 35 Tahun 2009 Tentang Narkotika dan literatur terkait. Metode penelitian yang digunakan terdiri dari berbagai cara dan kegiatan yang dilakukan dalam rangka mengumpulkan data-data dan bahan-bahan yang diperlukan untuk melengkapi penelitian ini.

b. Pendekatan Masalah

Terdapat dua pendekatan masalah yang digunakan dalam penelitian ini yaitu statute approach dan conceptual approach. "Statute approach berupa legislasi dan regulasi." Marzuki (2006, hal. 97). Statute approach merupakan pendekatan yang dilakukan dengan cara mengidentifikasi dan membahas peraturan perundang-undangan yang berlaku, yang berkaitan dengan 
permasalahan yang dibahas. Kemudian conceptual approach merupakan pendekatan masalah yang didasarkan pendapat para sarjana atau doktrin-doktrin ilmu hukum yang berhubungan dengan Tindak Pidana Narkotika.

c. Bahan Hukum

Bahan hukum yang digunakan dalam penelitian ini berupa bahan hukum primer dan bahan hukum sekunder. Bahan Hukum Primer, yaitu bahan hukum yang mempunyai kekuatan hukum yang bersifat mengikat. Dalam hal ini bahan hukum yang digunakan adalah peraturan perundang-undangan yang terkait yakni, Kitab Undang-undang Hukum Pidana, Undangundang Nomor 35 Tahun 2009 Tentang Narkotika, serta Putusan Nomor 2733/Pid.B/2014/PN.Sby.

Bahan Hukum Sekunder, yaitu bahan hukum yang berupa doktrin-doktrin, asas-asas, tulisan-tulisan ilmiah yang dapat ditemukan dalam berbagai literatur yang erat hubungannya dengan bahan hukum primer serta terkait dengan permasalahan penyalahgunaan Narkotika serta pertanggungjawaban pidananya.

d. Langkah Penulisan

Penulisan diawali dengan melakukan pengumpulan bahan hukum melalui studi kepustakaan, yaitu dengan inventarisasi semua bahan hukum yang berkaitan dengan pokok permasalahan, kemudian mengklarifikasi bahan hukum yang terkait lalu setelah itu bahan hukum tersebut disusun secara sistematik untuk lebih mudah dalam membaca dan mempelajarinya. Penulisan ini menggunakan penalaran yang bersifat deduktif yang berarti diawali dari hal umum yang telah diketahui maupun pengetahuan hukum yang bersifat umum yang diperoleh dari peraturan perundang-undangan dan literatur yang akhirnya mengarah kepada hal yang bersifat lebih khusus sehingga diperoleh suatu jawaban dari permasalahan yang bersifat khusus. Selanjutnya pembahasan digunakan penafsiran sistematis dengan mengaitkan pengertian antara peraturan perundang-undangan yang ada serta pendapat sarjana yang ditujukan untuk mengetahui serta memahami permasalahan yang dibahas.

\section{Hasil Penelitian dan Pembahasan}

Peredaran Narkotika telah banyak dilakukan dengan berbagai cara, salah satunya adalah pada kasus ditemukannya narkotika di dalam helm milik NS. Adapun kronologis singkat dalam perkara tersebut berawal pada waktu NS pada saat perjalanan pulang laju kendaraan Terdakwa dihentikan oleh petugas Polisi Sektor Genteng Surabaya di Jalan Raya Ketabang Kali Surabaya tepatnya di depan Taman Prestasi, petugas tersebut langsung melakukan pemeriksaan dan penggeledahan, mulai dari tas, kantong baju milik NS dan jok sepeda motor tetapi petugas tidak menemukan barang yang dicurigai yaitu Narkotika jenis sabu-sabu. Lalu Petugas Kepolisian menyuruh NS untuk melepas helm yang dipakai oleh NS dan ketika dilepas petugas menemukan barang yang ada di dalam helm milik NS tersebut. Setelah ditemukan barang tersebut, petugas menanyakan kepemilikan barang tersebut namun NS menyangkal memiliki barang tersebut. Lalu NS meminta untuk melihat rekaman CCTV sepeda motor NS yang diparkir di halaman Gedung DPRD Surabaya. Dari rekaman tersebut tidak ada orang yang mendekati sepeda motor 
Jurnal Yustika

Vol. 22 No. 1, Des 2019

Halaman | 67

Proses Pembuktian

Penguasaan

Narkotika yang

Disimpan di Dalam

Helm

Antonius Sony Wijanarko

milik NS maupun menaruh barang berupa Narkotika jenis sabu-sabu di dalam helm milik NS. Perbuatan NS tersebut ditindaklajuti ke pengadilan.

Dalam kewenangannya, Penuntut Umum mempunyai kewajiban untuk mendakwakan tindak pidana yang dituntut kepada terdakwa di muka persidangan dengan ketentuan undangundang yang berlaku. Terkait dengan kasus ini jaksa penuntut umum Surabaya telah mendakwakan bahwa terdakwa telah melanggar ketentuan sebagaimana dijelaskan dalam Pasal 112 ayat (1) Undang-undang Narkotika yang memiliki unsur-unsur yang terpenuhi oleh kasus tersebut.

Unsur yang pertama adalah 'Setiap orang'. Undang-undang tidak secara tegas memberikan pengertian apa yang dimaksudkan dengan unsur "setiap orang", namun menurut doktrin, "Setiap orang" selalu diartikan sebagai subyek hukum sebagai pendukung hak dan kewajiban, baik itu berupa orang (natuurlijke persoon) maupun badan hukum (rechts persoon) sebagai pendukung hak dan kewajiban tanpa kecuali, yang dapat dipertanggungjawabkan segala tindakan-tindakannya. "Setiap orang" yang dimaksudkan di sini, adalah orang pribadi, diajukan ke persidangan sebagai terdakwa, yang dapat dimintakan pertanggungjawaban pidananya, karena dianggap telah melakukan suatu perbuatan pidana. Bahwa dalam persidangan telah dihadapkan terdakwa yaitu NS dengan jati diri sebagaimana pada awal putusan, yang diduga telah melakukan suatu tindak pidana dan dalam persidangan terdakwa terlihat sehat jasmani dan rohani mampu dan mengerti terhadap dakwaan yang disampaikan kepadanya, maka dengan demikian unsur "Setiap orang" telah terpenuhi.

Unsur yang berikutnya adalah 'Tanpa hak atau melawan hukum'. Unsur ini memiliki maksud dan pemahaman suatu perbuatan haruslah berdasarkan hukum dalam undang-undang Narkotika seseorang yang memiliki Narkotika haruslah dilengkapi surat izin dari pihak yang berwenang baik berupa resep dari dokter ataupun surat dari instansi yang terkait. Narkotika hanya dapat digunakan untuk kepentingan pelayanan kesehatan dan/atau ilmu pengetahuan dan teknologi, sedangkan khusus untuk Narkotika golongan I dilarang digunakan untuk kepentingan pelayanan kesehatan dan dalam jumlah terbatas Narkotika golongan I dapat digunakan untuk kepentingan pelayanan kesehatan dan dalam jumlah terbatas Narkotika golongan I dapat digunakan untuk kepentingan pengembangan ilmu pengetahuan dan teknologi dan untuk reagensia diagnostic, serta reagensia laboratorium setelah mendapat persetujuan Menteri atas rekomendasi Kepala Badan Pengawas Obat dan Makanan, oleh karenanya yang mempunyai hak untuk memperoleh, menanam, menyimpan dan menggunakan Narkotika untuk kepentingan ilmu pengetahuan dan teknologi adalah lembaga ilmu pengetahuan yang berupa lembaga pendidikan dan pelatihan serta penelitian dan pengembangan yang diselenggarakan oleh pemerintah ataupun swasta setelah mendapat izin menteri. Bahwa berdasarkan uraian dan fakta-fakta yang terungkap di persidangan diketahui di mana NS bukanlah orang yang mendapat kuasa dari suatu lembaga ilmu pengetahuan yang telah mendapat izin dari Menteri sebagaimana yang disebutkan di atas, oleh karenanya terdakwa tidaklah memiliki kewenangan untuk itu, dengan demikian Majelis Hakim berpendapat unsur "tanpa hak melawan hukum" telah terpenuhi. 
Unsur yang terakhir adalah Memiliki, menyimpan, menguasai, atau menyediakan. Pada unsur ini terdapat berbagai kemungkinan yang dilakukan sebelum menyalahgunakan Narkotika. Para pengguna sebelum menggunakan narkotika terlebih dahulu akan menyimpan atau menguasai, memiliki atau membawa narkotika. Namun tidak hanya pengguna yang saja yang melalui tahap ini melainkan para pengedar juga akan menyimpan atau menguasai, memiliki atau membawa narkotika sebelum akan mengedarkan. Sehingga sehingga unsur ini dapat dikatakan sebagai tahap awal dari adanya penyalahgunaan Narkotika.

Berdasarkan uraian pasal yang didakwakan di atas, penuntut umum menyatakan bahwa NS telah memiliki dan menguasai Narkotika Golongan I jenis sabu-sabu yang diduga mengandung crystal methamphetamine yang terdaftar dalam Golongan I nomor urut 61 Lampiran Undang-undang Narkotika. Sehingga NS telah memenuhi unsur pasal sebagaimana dimaksud dalam Pasal 112 Undang-undang Narkotika. Namun dalam menentukan kebenaran dalam peristiwa seperti yang didakwakan penuntut umum harus diiringi dengan pembuktian yang sah untuk meyakinkan atau memastikan bahwa sesuatu itu sebagai sesuatu yang benar.

Pasal 184 ayat (1) KUHAP mengatur mengenai alat bukti yang sah untuk pembuktian dalam perkara pidana, yakni :
a. Keterangan saksi;
b. Keterangan ahli;
c. Surat;
d. Petunjuk, dan;
e. Keterangan terdakwa

Selain alat bukti yang ditentukan dalam KUHAP, Undang-undang Narkotika juga mengatur mengenai alat bukti tersendiri yang diatur pada Pasal 86, yakni:

1. Penyidik dapat memperoleh alat bukti selain sebagaimana dimaksud dalam KUHAP;

2. Alat bukti sebagaimana dimaksud pada ayat (1) berupa :

a. Informasi yang diucapkan, dikirimkan, diterima, atau disimpan secara elektronik dengan alat optic atau yang serupa dengan itu dan

b. Data rekaman atau informasi yang dapat dilihat, dibaca, dan/atau didengar, yang dapat dikeluarkan dengan atau tanpa bantuan suatu sarana baik yang tertuang di atas kertas, benda fisik apa pun selain kertas maupun yang terekam secara elektronik, termasuk tetapi tidak terbatas pada :

1) Tulisan, suara, dan/atau gambar;

2) Peta, rancangan, foto atau sejenisnya; atau huruf, tanda, angka, simbol, sandi, atau perforasi yang memiliki makna dapat dipahami oleh orang yang mampu membaca atau memahaminya

Keberadaan alat bukti sangat penting dalam menentukan apakah seseorang memenuhi unsur-unsur pidana terhadap ketentuan pidana yang didakwakan padanya sehingga dapat ditentukan apakah orang tersebut dapat dikenakan pertanggungjawaban atas perbuatannya atau tidak. 
Jurnal Yustika

Vol. 22 No. 1, Des 2019

Halaman | 69

Proses Pembuktian

Penguasaan

Narkotika yang

Disimpan di Dalam Helm

Antonius Sony Wijanarko

"Pembuktian merupakan ketentuan-ketentuan yang berisi penggarisan dan pedoman tentang tata cara-cara yang dibenarkan Undang-undang membuktikan kesalahan yang didakwakan kepada terdakwa." (Harahap, 2013, hal. 273). Jadi pembuktian merupakan suatu ketentuan yang mengatur alat-alat bukti yang dibenarkan Undang-Undang yang boleh dipergunakan hakim membuktikan kesalahan yang didakwakan.

"Hukum pembuktian adalah sebagian dari hukum acara pidana yang mengatur macammacam alat bukti yang sah menurut hukum, sistem yang dianut dalam pembuktian, syaratsyarat dan tata cara mengajukan alat bukti tersebut serta kewenangan hakim untuk menerima, menolak dan menilai suatu pembuktian." (Sasangka dan Rosita, 1996, hal. 6)

"Untuk menyatakan salah atau tidak seorang terdakwa, tidak cukup berdasarkan keyakinan hakim semata-mata atau hanya semata-mata didasarkan atas keterbuktian menurut ketentuan dan cara pembuktian dengan alat-alat bukti yang ditentukan undang-undang. Seorang terdakwa baru dapat dinyatakan bersalah apabila kesalahan yang didakwakan kepadanya dapat dibuktikan dengan cara dan dengan itu "dibarengi" dengan keyakinan hakim." (Harahap, 2012, hal. 280)

Sehingga atas keterbuktian dengan sekurang-kurangnya dua alat bukti yang sah, hakim memperoleh keyakinan bahwa tindak pidana benar-benar terjadi dan bahwa terdakwalah yang bersalah melakukannya. "Alasan pembuat undang-undang merumuskan Pasal 183 KUHAP ditujukan untuk mewujudkan suatu ketentuan yang seminimal mungkin dapat menjamin tegaknya kebenaran sejati serta tegaknya keadilan dan kepastian hukum." (Yahya Harahap, 2001, hal.256).

Pasal 30 ayat (1) huruf a Undang-undang Nomor 16 Tahun 2004 tentang Kejaksaan menentukan bahwa di bidang pidana kejaksaan mempunyai tugas dan wewenang yaitu melakukan penuntut untuk melimpahkan perkara pidana ke Pengadilan Negeri yang berwenang dalam hal dan menurut cara yang diatur dalam undang-undang ini dengan permintaan supaya diperiksa dan diputus oleh Hakim di sidang Pengadilan.

Berkaitan dengan wewenang Penuntut Umum untuk melakukan penuntutan, terdapat hal lain yang berhubungan yaitu membuat surat dakwaan yang diatur dalam Pasal 14 huruf $\mathrm{d}$ KUHAP. Surat dakwaan merupakan perumusan dari tindak pidana yang dituduhkan yang sementara disimpulkan dari surat-surat pemeriksaan pendahuluan. Berdasarkan hasil pemeriksaan pendahuluan, dalam interogasi terhadap NS yang menerangkan bahwa barang bukti berupa sabu-sabu adalah bukan miliknya dan NS tidak mengetahui adanya sabu-sabu tersebut di dalam helm miliknya. Sangkalan inilah yang membuat Hakim merasa ragu atas dugaan menguasai atau memiliki Narkotika sebagaimana telah didakwakan oleh jaksa penuntut umum, sehingga dengan alat bukti ditemukannya sabu-sabu di dalam helm milik terdakwa serta dua orang saksi tidak dapat memberikan keyakinan kepada Hakim pada proses pembuktian di Pengadilan.

Beban pembuktian pada dasarnya ada pada penyidik, penyidik berupaya sebaik-baiknya dalam memenuhi ketentuan dalam Undang-undang yaitu bahwa suatu peristiwa yang terjadi 
diduga atau merupakan tindak pidana maka dilakukan penyelidikan yang bertujuan untuk mencari keterangan dan bukti untuk mencari kebenaran dalam suatu peristiwa pidana.

Penyidik merupakan tugas dari pihak kepolisian di mana polisi diharuskan untuk mengumpulkan barang bukti yang selengkap-lengkapnya. Proses penyidikan selain diatur dalam Pasal 7 ayat (1) KUHAP juga didasarkan pada ketentuan dalam Pasal 1 butir ke-9 UndangUndang Nomor 2 Tahun 2002 tentang Kepolisian RI. Sedangkan penyelidikan merupakan serangkaian tindakan penyidik untuk mencari dan menemukan suatu peristiwa yang diduga sebagai tindak pidana guna menentukan dapat atau tidaknya dilakukan penyidikan menurut cara yang diatur dalam Undang-undang. Selanjutnya di dalam Pasal 1 butir ke-13, dinyatakan bahwa penyidikan adalah serangkaian tindakan penyidik dalam hal dan menurut cara yang diatur dalam Undang-undang untuk mencari serta mengumpulkan bukti, yang dengan bukti itu membuat terang tentang tindak pidana yang terjadi dan guna menemukan tersangka.

Dalam proses pembuktian kasus Narkotika, seringkali alat bukti yang digunakan adalah dua orang saksi, barang bukti sejumlah narkoba, hasil tes urin atau tes darah milik terdakwa. Hal tersebut memang sudah cukup kuat dalam pembuktian sebagaimana dimaksud dalam KUHAP, namun sistem pembuktian negatif yang dianut oleh KUHAP mengharuskan adanya keyakinan Hakim agar terdakwa dapat dijatuhi sanksi pidana, sehingga di sini peran penyidik dan penyelidik sangat dibutuhkan dalam mencari alat bukti-alat bukti yang dapat meyakinkan Hakim. Selain alat bukti-alat bukti yang sering digunakan dalam proses pembuktian kasus Narkotika, terdapat alat bukti sidik jari yang dapat digunakan sebagai petunjuk atas kepemilikan atau penguasaan dari suatu Narkotika.

Penjelasan Pasal 75 huruf f Undang-undang Narkotika menjelaskan bahwa, "tes urine, tes darah, tes rambut, dan tes bagian tubuh lainnya dilakukan sesuai dengan perkembangan ilmu pengetahuan dan teknologi untuk membuktikan ada tidaknya Narkotika di dalam tubuh satu orang atau beberapa orang. Berdasarkan pada penjelasan tersebut maka Nampak bahwa tes sidik jari merupakan bagian tubuh yang dapat diidentifikasi dan merupakan suatu alat bukti untuk menentukan siapakah pemilik atau yang menguasai suatu Narkotika.

Berdasarkan pada Pasal 187 huruf c KUHAP tersebut, hasil tes sidik jari yang berbentuk berita acara laboratoris merupakan surat yang dibuat oleh seorang yang ahli daktiloskopi dalam melakukan uji coba spesimen guna menentukan sidik jari milik siapa yang terdapat pada bungkus Narkotika tersebut., "..bentuk surat yang disebut pada huruf a, b, dan c adalah "surat resmi" yang dibuat pejabat yang berwenang atau berdasar ketentuan atau surat keterangan ahli yang bersifat khusus mengenai keadaan tertentu yang dibuat atas sumpah jabatan atau dikuatkan dengan sumpah." (Harahap, 2012, hal. 312). "Surat tersebut dengan sendirinya bernilai sebagai alat bukti yang sah, sejak surat itu diperbuat." (Harahap, 2012, hal. 307)

Setiap orang mempunyai sidik jari yang berbeda-beda karena sidik jari merupakan identitas pribadi dan tidak ada di dunia ini yang memiliki sidik jari sama. Sidik jari adalah hasil dari reproduksi tapak-tapak jari, baik yang sengaja diambil atau dicapkan dengan tinta maupun bekas yang berada pada suatu benda yang pernah terpegang atau tersentuh dengan kulit telapak tangan atau kaki. Bekas-bekas yang termasuk dalam definisi tersebut adalah bekas-bekas yang 
Jurnal Yustika

Vol. 22 No. 1, Des 2019

Halaman | 71

Proses Pembuktian

Penguasaan

Narkotika yang Disimpan di Dalam Helm

Antonius Sony Wijanarko ditinggalkan oleh jari telapak tangan, telapak kaki dan jari kaki. Garis papiliar adalah garis-garis halus yang muncul pada kulit dan membentuk sidik jari.

Fungsi identifikasi yaitu merupakan salah satu fungsi bantuan teknis yang dapat dipergunakan oleh kepolisian RI dalam hal ini penyidik dan penyelidik dalam upaya mengungkap kasus tindak pidana tidak dapat dilakukan hanya dengan pemeriksaan saksi saja.

Penerapan sidik jari Oleh Polri telah ditentukan oleh Undang-undang Nomor 13 Tahun 1961 tentang ketentuan-ketentuan pokok Kepolisian Negara dan KUHAP. Dalam hal pelaksanaan pemeriksaan sidik jari diatur dalam Pasal 11 ayat (1) huruf a Perkapolri Nomor 20 Tahun 2010 tentang koordinasi, pengawasan dan pembinaan, penyidikan bagi penyidik pegawai negeri sipil. Di samping itu, hasil pemeriksaan sidik jari yang dilakukan oleh petugas identifikasi yang tertuang dalam berita acara atau surat keterangan, mempunyai kekuatan bukti dalam sidang pengadilan (surat keterangan ahli) atau alat bukti surat yang kedua alat bukti ini sah menurut hukum sesuai Pasal 184 KUHAP.

Dalam pemeriksaan sidik jari tentunya tidak lepas dari biaya. Namun mengingat banyaknya kasus Narkotika baik pengedaran maupun penyalahgunaan, upaya pembuktian pada kasus Narkotika harus dilakukan dengan teliti berdasarkan bukti-bukti yang jelas dan dapat dipertanggungjawabkan. Guna pemberantasan penyalahgunaan dan peredaran Narkotika, biaya yang diperlukan dalam proses pembuktian akan sepadan dengan upaya tersebut. Semua itu bertujuan agar dalam pengadilan dapat menggunakan petunjuk atau alat bukti yang sah dengan arif dan bijaksana serta harus lebih dahulu mengadakan pemeriksaan dengan penuh kecermatan dan saksama terhadap petunjuk yang ada, sehingga dalam memutus perkara jangan sampai melepaskan orang yang bersalah atau menghukum orang yang tidak bersalah sehingga keadilan dapat benar-benar terwujud dalam Negara.

Hasil pemeriksaan sidik jari pada dasarnya dapat dipergunakan sebagai alat bukti dalam pembuktian perkara pidana. Hasil pemeriksaan ini merupakan salah satu alat bukti yang diatur dalam Pasal 184 ayat (1) KUHAP yakni alat bukti surat. Hal tersebut berdasarkan pada Pasal 187 huruf e KUHAP yang mengatur, "Surat sebagaimana tersebut pada Pasal 184 ayat (1) huruf c, dibuat atas sumpah jabatan atau dikuatkan dengan sumpah adalah surat keterangan dari seorang ahli yang memuat pendapat berdasarkan keahliannya mengenai sesuatu atau sesuatu keadaan yang diminta secara resmi daripadanya."

Berdasarkan pada Pasal 187 huruf c KUHAP tersebut, hasil tes sidik jari yang berbentuk berita acara laboratoris merupakan surat yang dibuat oleh seorang yang ahli daktiloskopi dalam melakukan uji coba spesimen guna menentukan sidik jari milik siapa yang terdapat pada bungkus Narkotika tersebut., "..bentuk surat yang disebut pada huruf a, b, dan c adalah "surat resmi" yang dibuat pejabat yang berwenang atau berdasar ketentuan atau surat keterangan ahli yang bersifat khusus mengenai keadaan tertentu yang dibuat atas sumpah jabatan atau dikuatkan dengan sumpah." (Harahap, 2012, hal. 312). "Surat tersebut dengan sendirinya bernilai sebagai alat bukti yang sah, sejak surat itu diperbuat." (Harahap, 2012, hal. 307)

Terkait pada kasus ini sangat disayangkan jaksa penuntut umum tidak memerintahkan penyidik untuk melakukan pemeriksaan sidik jari terhadap barang bukti sabu-sabu yang 
ditemukan di dalam helm milik NS sesaat setelah NS membantah bahwa barang bukti tersebut adalah miliknya. Berdasarkan penjelasan tentang hasil pemeriksaan sidik jari dapat menjadi alat bukti yang kuat di muka persidangan dalam proses pembuktian, dalam hal ini jaksa penuntut

umum dapat memerintahkan penyidik untuk melakukan pemeriksaan sidik jari yang diuji oleh seorang ahli daktiloskopi atau seseorang yang ahli dalam sidik jari yang kemudian hasil uji laboratoris tersebut dituangkan dalam berita acara berupa surat keterangan ahli.

"Penggeledahan adalah tindakan penyidik yang dibenarkan undang-undang untuk memasuki dan melakukan pemeriksaan di rumah tempat kediaman seseorang atau untuk melakukan pemeriksaan terhadap badan dan pakaian seseorang." (Harahap, 2012, hal. 249).

Terkait dengan kasus ini tindakan polisi dalam melakukan penggeledahan badan ditempat tanpa disertai surat perintah penggeledahan sudah sesuai dengan ketentuan yang berlaku sebagaimana dijelaskan dalam Pasal 34 KUHAP ayat (1), karena pada kasus ini NS telah tertangkap tangan saat sedang mengendarai motor miliknya.

Tujuan keharusan adanya surat izin Ketua Pengadilan Negeri dalam tindakan penggeledahan rumah, dimaksudkan untuk menjamin hak asasi seseorang atas rumah kediamannya, juga agar penggeledahan tidak merupakan upaya yang dengan gampang dipergunakan penyidik tanpa pembatasan dan pengawasan. Demi untuk membatasi laju penggeledahan yang kurang dapat dipertanggungjawabkan serta tidak dipergunakan secara semau sendiri, pembuat undang-undang membebani syarat, yaitu harus lebih dulu ada surat izin Ketua Pengadilan Negeri setempat.

Pada Pasal 112 Undang-undang Narkotika memiliki unsur-unsur yang merupakan tahap awal dari tindak pidana penyalahgunaan Narkotika, sehingga banyak kemungkinan yang menjadi tujuan dari tahap awal tersebut. Semua itu bergantung pada bagaimana jaksa penuntut umum mencari bukti-bukti serta membuktikan pada proses pemeriksaan dimuka persidangan.

\section{Kesimpulan}

Berdasarkan uraian dan pembahasan di atas maka dapat ditarik kesimpulan bahwa dalam proses pembuktian khususnya pada kasus Tindak Pidana Penyalahgunaan Narkotika, sangat menentukan putusan dalam Pengadilan, sehingga:

A. Penuntut umum yang berkewajiban untuk membuktikan, dapat menambahkan alat bukti dengan mengambil sampel sidik jari dari bungkus Narkotika yang ditemukan dalam helm milik NS dengan memerintahkan penyidik dan diperbantukan oleh seorang ahli daktiloskopi. Hasil sidik jari dapat menjadi bukti yang sah yaitu berupa surat sekaligus keterangan ahli sebagaimana disebutkan pada ketentuan Pasal 184 KUHAP dan akan membuktikan siapa yang memiliki atau menguasai Narkotika jenis sabu-sabu tersebut serta akan memberikan keyakinan terhadap Majelis Hakim dalam proses pembuktian.

B. Polisi sebagai penyidik, sebagaimana disebutkan pada ketentuan Pasal 32 KUHAP selain melakukan penggeledahan badan, penyidik juga dapat melakukan 
Jurnal Yustika

Vol. 22 No. 1, Des 2019

Halaman | 73

Proses Pembuktian

Penguasaan

Narkotika yang

Disimpan di Dalam Helm

Antonius Sony Wijanarko

penggeledahan rumah dan tempat-tempat lain seperti tempat NS bekerja dengan tujuan menemukan bukti-bukti yang dapat meyakinkan lebih pasti bahwa NS memang melakukan penguasaan terhadap Narkotika.

Terkait pada kasus ini, maka seharusnya Penuntut Umum dalam menuntut seseorang yang memang diduga bersalah menguasai Narkotika, pada tahap penyidikan harus sesuai dengan sebagaimana yang diatur dalam KUHAP sehingga penggeledahan rumah yang dijelaskan di atas harus dilakukan oleh penyidik.

Penuntut Umum yang mengajukan kasasi juga seharusnya dapat menambahkan alat bukti seperti alat bukti surat yang menyatakan adanya sidik jari terdakwa pada bungkus Narkotika yang ditemukan tersebut. Semua itu bertujuan agar Hakim dapat menggunakan petunjuk atau alat bukti yang sah dengan arif dan bijaksana serta harus lebih dahulu mengadakan pemeriksaan dengan penuh kecermatan dan saksama terhadap petunjuk yang ada berdasarkan hati nuraninya, sehingga dalam memutus perkara jangan sampai melepaskan orang yang bersalah atau menghukum orang yang tidak bersalah sehingga keadilan dapat benar-benar terwujud dalam Negara.

\section{Daftar Referensi}

Arliman, Laurensius, (2015), Penegakan Hukum dan Kesadaran Masyarakat, Yogyakarta: Deepublish Chazawi, Adami, (2002), Pelajaran Hukum Pidana, Jakarta: PT. Raja Grafindo Persada D, Soedjono, (1981), Pertanggungjawaban dalam Hukum Pidana, Bandung: Alumni Dahlan, (2017), Problematika Keadilan, Yogyakarta: CV.Budi Utama Hawari, Dadang, (1991), Penyalahgunaan Narkotika Dan Zat Adiktif, Jakarta: Balai Pustaka Harahap, Yahya, (2008), Pembahasan Permasalahan dan Penerapan KUHAP, Jakarta: Sinar Grafika Kansil, C.S.T, (1989), Pengantar Ilmu Hukum dan Tata Hukum Indonesia, Jakarta: Balai Pustaka Makarao, Mohammad Taufik, (2003), Tindak Pidana Narkotika, Jakarta: Ghalia Indonesia Mappiase, Syarif, (2015), Logika Hukum Pertimbangan Putusan Hakim, Jakarta: Prenadia Group Moeljatno, (2008), Asas-Asas Hukum Pidana, Yogyakarta: Rineka Cipta

Mustofa, Wildan Suyuti, (2013), Kode Etik Hakim, Jakarta: Prenadia Group Remmelink, Jan, (2008), Hukum Pidana, Jakarta: Gramedia Pustaka Sasangka, Hari, (2003), Hukum Pembuktian Dalam Perkara Pidana, Bandung: Mandar Maju Yudhayana, (1993), Penuntun Daktiloskopi, Jakarta: Pusat Indentifikasi Polri 